\title{
The Opportunities and Challenges That the Belt and Road Initiative Brings: Analysis from Perspective of China-Pakistan Economic Corridor
}

\author{
Ruosi Wen, Hummera Saleeem \\ School of International Organization, Wuhan University of Technology, Wuhan, China \\ Email: wenmoumou9@qq.com
}

How to cite this paper: Wen, R. S., \& Saleeem, H. (2021). The Opportunities and Challenges That the Belt and Road Initiative Brings: Analysis from Perspective of China-Pakistan Economic Corridor. American Journal of Industrial and Business Management, 11, 675-691.

https://doi.org/10.4236/ajibm.2021.116044

Received: May 13, 2021

Accepted: June 25, 2021

Published: June 28, 2021

Copyright $\odot 2021$ by author(s) and Scientific Research Publishing Inc. This work is licensed under the Creative Commons Attribution-NonCommercial International License (CC BY-NC 4.0). http://creativecommons.org/licenses/by-nc/4.0/ (c) (7) (8) Open Access

\begin{abstract}
Driven by the Belt and Road Initiative (BRI), China and Pakistan as all-weather strategic partners announced a big move to build the China-Pakistan Economic Corridor (CPEC) in 2015, aiming to link Pakistan's Gwadar Port to China's Xinjiang autonomous region. CPEC leads two countries into economic cooperation in critical areas including manufacture, energy, logistics and transport. The Belt and Road initiatives (BRI) project could bring economic avenues to Pakistan and foster regional and cross-regional economic growth as well as trade integration between Central Asia, South Asia, West Asia and East Asia. This paper not only makes a theoretical analysis of BRI and CPEC but also explores the reason why CPEC may succeed from the perspectives of the balanced growth development theory and the neoclassical growth theory. Theoretically, openness and massive capital are key factors for less developed economies to transfer into a sustainable growth state. However, these countries are disadvantageous in both openness and capital funds. Therefore, an external big push of massive investment is needed for them. Only through investing simultaneously in most complementary industries and regions, can they make economies to step into the growing path, and then to grow sustainably. Once the big push ignites the growth engine, economies acquire advantages of catch-up mechanism and converge to steady state. Therefore, CPEC focusing on aid-for-trade as well as substantial infrastructure development is capable of boosting economic prosperities for both China and Pakistan. In addition to theoretical analysis, this article identifies different types of socio-political impediments against BRI and CPEC, ranging from environmental aspects to socio-political structures. Pakistan has long been struggling with socio-political factors: low literacy rate, turbulent politi-
\end{abstract}


cal situation, terrorist attacks, crimes, wars and corruption. All these negative factors pose essential challenges for transnational investment and infrastructure projects.

\section{Keywords}

BRI, CPEC, Balanced Growth, Big Push, Catch-up Effect

\section{Introduction}

The Belt and Road Initiative (BRI) is a mega plan launched by China in 2013 to activate the economic vitality of the countries and regions along the New Silk Road. With the progress of the BRI plan, regional economic and trade integration could be substantially promoted among Central Asia, South Asia, West Asia, and East Asia. It is estimated that more than 66 countries will benefit from this plan. However, it may cause some serious negative impacts, including environmental damages, increasing income inequality, cultural conflict, and intention among ethnic groups. Both opportunities and challenges exist.

Pakistan is an all-weather strategic partner of China, as well as an important country along Belt and Road. Besides, Pakistan is one of a typical developing country since it shares with other countries many social and political features that matter for economic development, such as weak governance, lower literacy, deficient infrastructure and political instability. These common features will determine the future of BRI. Therefore, this paper focuses on the case of Pakistan to analyze the opportunities and challenges of BRI.

Pakistan not only has advantages in the labor force and internal market, but also owns deep-water ports that may greatly shorten the distance of logistics transportation of oils and manufactures which China mainly trade with Gulf countries and European countries. In addition to the bright side, as Pakistan has long been struggling with socio-political factors that seriously hinder economic development, including low literacy rate, turbulent political situation, terrorist attacks, crimes, wars, and corruption, BRI faces essential challenges in terms of transnational investment and infrastructure projects in Pakistan.

Under the framework of BRI, China and Pakistan are cooperating to develop an economic zone called the China-Pakistan Economic Corridor (CPEC), which is designed as a flagship project of the BRI. CPEC links Pakistan's Gwadar Port to China's Xinjiang autonomous region, concentrating on manufacturing, energy and transport infrastructure. CPEC consists of two major projects, of which one is Gwadar port and the other is the quaternity channel of road, railway, oil pipe and optical fiber line that connect Gwadar port, Pakistan to Xinjiang, China. With the help of CPEC, China and Pakistan cooperate to invest on infrastructure, agriculture, water conservancy, energy, and communication. Various industrial parks, as well as free trade zone, will be erected in the corridor. In Pakistan, energy security issues and poor infrastructure are two main hurdles of economic 
growth and poverty reduction. Apparently, CPEC enables Pakistan to achieve regional harmonization and inclusive growth. With the effort of Xinjiang Production and Construction Corporation, China has invested more than $\$ 55$ billion in infrastructure development and energy sector to overcome the problems mentioned above (Sial, 2014; Sender \& Stacey, 2017).

CPEC is a mega game-changer project for Pakistan since it will significantly improve the economic development of Pakistan. Moreover, while CPEC is boosting the investment opportunities in Pakistan, the economic growth of south and southwest Asia countries is also strengthened. Therefore, if CPEC is successful, then BRI is successful.

However, CEPC still faces many challenges. There exists long-standing tension between South Asian countries, especially between Pakistan and India. The socio-political structure in Pakistan is unstable and uncertain, and local extremists of the region are rampant, putting investments at risk. These adverse environments are harmful for the BRI projects.

Geographically, the western part of Pakistan is less developed and suffers from natural disasters. While the eastern part of Pakistan is better developed with a vast population. To attain sustainable economic growth and development, it is essential to address the critical issues of Pakistan. The infrastructure developments, enough energy, valid governance, balanced regional growth and the war against both terrorism and extremism are the main priorities of for Pakistan's government to deal with to ensure the smooth progress of CPEC.

This study focuses mainly on a theoretical analysis of the benefits and challenges of the CPEC under the Belt and Road Initiative. The paper develops a theory to explore why CPEC has the root of success and explains why CPEC is valuable for both Pakistan and China. In addition, challenges that may defeat CPEC are also discussed.

The rest of the paper is organized as follows. Section 2 surveys relevant research results and outlines a brief theoretical analysis of the economic corridor. Section 3 is an overview description of BRI and CPEC, including the economic profile of Pakistan and an introductive overview of BRI. Theoretical analysis of CPEC is the key content of this study, which forms Section 4. Section 5 discusses the challenges that CPEC face, which is also of high importance. Finally, Section 6 explains the conclusion and policy inferences.

\section{A Theoretical Overview of Economic Corridor}

Economists in the fields of international trade and regional integration have paid attention to aid-for-trade practice and economic corridors recently. The BRI takes the form of aid-for-trade. Generally, China supplies capital funds to countries along BRI road to vivify trade between China and those countries. To enhance trade via aid along Belt and Road, economic corridors are developed as a representative example, which could attract significant attention from different economies. 
When countries open their economies to the world, they need to make them more competitive. For less developed countries, competition is mainly determined by infrastructure. Therefore, aid for infrastructure development is a priority in BRI. Economic corridors are designed to help host countries meet infrastructure requirements. Planned by economics corridors, massive funding is allocated into telecommunication, roads, power, warehouse, and transportation. When economic corridors build a thorough infrastructure system, it attracts the inflow of overseas capital and encourages industrial agglomeration. Then industrialization is on the march, assembling the goods globally within global production networks (GPNs) (Athukorala, 2014; Yeats, 2011).

The term economic corridor has no standard definition. When BRI develops an economic corridor to carry out an aid-for-trade plan, the word 'economic corridor' can be understood as a development of the geographical area supported by a set of favorable economic policies. The development consists of trade facilitation, logistics improvements, road construction and investment in green financing. The construction of intermodal and multimodal transporting facilities is the key content of infrastructure development, as it improves connectivity between regions. As a result, the transportation cost of the goods and services will be minimized through the economic corridor's gateway, and manufactures will benefit from industrial agglomeration in the corridor. In one word, the economic corridor can provide a gateway to sell products and services globally through significant infrastructure development projects for developing countries.

To ensure the success of the economic corridor, governments should make the best effort. Firstly, economic policy and planning need to be highly focused on the development of corridor infrastructure in accordance with global infrastructure and global logistic service (Rimmer, 2014). The economic corridor would be successful if it could act as a combination of trade facilitation reforms and infrastructure developments. Secondly, governments also need to encourage entrepreneurial capabilities, improve business environments, promote skill development, and facilitate labor mobility across regions. Thirdly, governments should provide private sectors with services of coordination and consultation.

When the construction of infrastructure systems is completed, governments need to advance the developments of industrial clusters. A well-planned effective spatial industrial policy helps industrial agglomeration, and hence improves the development of an economic corridor. The cluster of industries inside the corridor can get benefits from technology transfer, productivity spillover, and logistics sharing. Agglomeration economies can raise firm-level productivity (Krugman, 1991; Söderbaum \& Taylor, 2001; Newman \& Page, 2017).

Perhaps countries along BRI road can successfully develop the economic corridor and boost economic growth, nevertheless, they may also face a tough challenge in finding a way to obtain a win-win outcome. Local residents deserve the benefits from economic corridor development. However, due to development stages, political setting, and socio-economic factors of the country/region, go- 
vernance mechanisms may be distorted so that economic growth fails to benefit people equally (World Bank, 2019; Mitra et al., 2016). The competent government policies can promote the industrial sector through effective industrial policy (PwC, 2017).

\section{BRI and CPEC}

\subsection{Economic Profile of Pakistan}

Asian countries are becoming a hub of economic growth and development. They have an enormous population but less developed economies, so that they eagerly yearn for industrialization and poverty reduction. If they had chances, they would like to do everything they can to get rich. Therefore, they possess great potential for economic development.

China and Pakistan are among the most populous countries in the world. As one of the fastest growth economies in the world, China has experienced rapid technological development, as well as quick enlargement of trade size in the past few decades. Since the reforms and opening up of the policy were inaugurated in 1978, the country has witnessed substantial economic expansion. The gross domestic product of Pakistan reached 278 billion US dollars, almost 12 times the figure in 1978. As an important all-around partner of China, Pakistan is a big developing country. Like many other developing countries, Pakistan needs to boost economic growth to improve the standard of living. Many developing economies are suffering from a lot of macroeconomic constraints, one of them is Pakistan. The living standard of the major population in Pakistan is under the poverty line. The total population of Pakistan in 2017 is estimated to be 197 million. (Table 1)

Table 1. Major exports of Pakistan in billion rupees and \% share.

\begin{tabular}{ccccccccc}
\hline Years & \multicolumn{2}{c}{$2014-15$} & \multicolumn{2}{c}{$2015-16$} & \multicolumn{2}{c}{ 2016-17 } & \multicolumn{2}{c}{ 2017-18 (Provisional) } \\
\hline Country & Rupees. \% & Share Rupees. \% & Share Rupees. \% Share & Rupees. & \% Share \\
\hline USA & 374.4 & 16 & 364.8 & 17 & 361.1 & 17 & 222.5 & 16 \\
CHINA & 219.9 & 9 & 174 & 8 & 153.8 & 7 & 96.3 & 7 \\
AFGHANISTAN & 198.8 & 8 & 149.9 & 7 & 133.1 & 6 & 95.4 & 7 \\
UNITED KINGDOM & 160.2 & 7 & 164.7 & 8 & 163.1 & 8 & - & - \\
GERMANY & 119 & 5 & 118 & 5 & 125.1 & 6 & 82.2 & 6 \\
U.A.E & 102.9 & 4 & 85.5 & 4 & 83 & 4 & 50.3 & 4 \\
BANGLADESH & 70.7 & 3 & 72.3 & 3 & 65.4 & 3 & 41.9 & 3 \\
ITALY & 67.6 & 3 & 67.7 & 3 & 68.6 & 3 & 44.2 & 3 \\
SPAIN & 81.7 & 3 & 84.3 & 4 & 85.5 & 4 & 61.7 & 4 \\
FRANCE & 38.2 & 2 & 36 & 2 & 38.8 & 2 & 24.5 & 2 \\
All Other & 964.1 & 40 & $\mathbf{8 4 9 . 6}$ & 39 & $\mathbf{8 6 0 . 7}$ & 40 & $\mathbf{5 7 6 . 2}$ & 41 \\
Total & $\mathbf{2 3 9 7 . 5 0}$ & 100 & $\mathbf{2 1 6 6 . 8 0}$ & 100 & $\mathbf{2 1 3 8 . 2 0}$ & 100 & $\mathbf{1 3 9 7 . 9 0}$ & 100 \\
\hline
\end{tabular}

Source: Pakistan Bureau of Statistics. 


\subsection{Over View of the BRI}

China launched the BRI project in 2013 to strengthen connectivity with countries in Asia, Africa, the Middle East, and Europe through road and railway, focusing on reducing the time of logistics. Figure 1 shows countries and regions along BRI. The upper dotted line in red is the belt, Silk Road inland, and the lower dotted line in blue is the road, i.e., silk road of the sea.

BRI is a substantial and significant plan since more than 62 percent of the population in the world who inhabit in, and more than 65 countries are located in this area. It is also ambitious and risky because fundamental factors are extremely complicated due to different cultures, religions, and political systems coexisting in this area. This project can create job opportunities as well as economic development, but the diplomatic condition, cultural shock, and socio-political structure are the major negative issues along with the BRI mega project.

China owns a fast-growing economy with a national income (GDP) of over $\$ 13.6$ trillion. It is expected that its GDP will double in 2050 on the basis of 2010, reaching $\$ 58.5$ trillion, up from $\$ 5.7$ trillion in 2010 (CHI, 2019). The economic globalization that China boosts is now moving towards the new era due to the progress of BRI, from which various countries along Belt and Silk Road and historical Silk Road will benefit. However, due to differences in political, socioeconomic and cultural conditions, the abilities of the countries to adopt transformative development are not the same.

Up to now, there have been seven economic corridors in progress (Schwab, 2018):

- China-Pakistan Economic Corridor (CPEC), from Western China to the Indian Ocean through Pakistan,

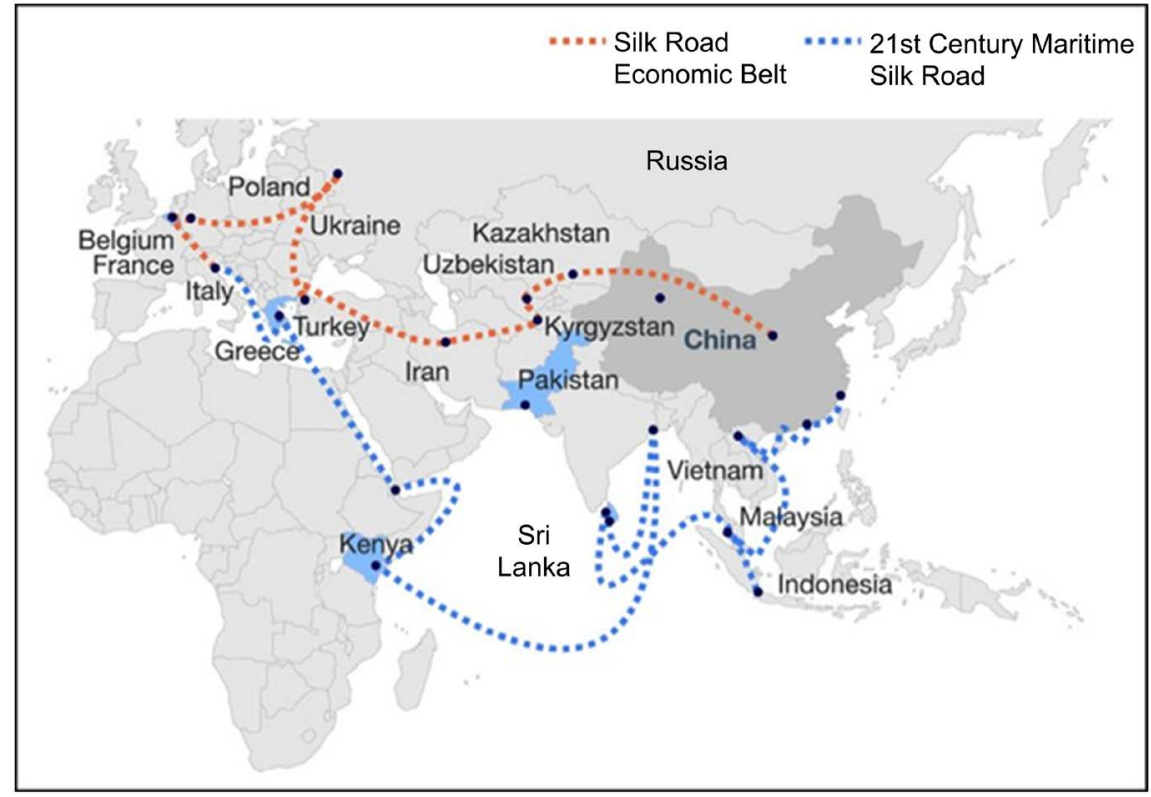

Figure 1. Map of the belt and road. 
- Eurasian Land-Bridge, from Western China to Western Russia,

- China-Mongolia-Russia Corridor, from Northern China to Eastern Russia,

- China-Central Asia-West Asia Corridor, from Western China to Turkey,

- China-Indochina Peninsula Corridor, from Southern China to Singapore,

- Bangladesh-China-India-Myanmar (BCIM) Corridor, from Southern China to Myanmar,

- Maritime Silk Road, from the Chinese Coast through Singapore to the Mediterranean.

\subsection{The Economic Corridor Model of China and Pakistan}

Pakistan and China form a strategic partnership, highly focusing on economic cooperation and trade between these two countries. As the major component of the economic partnership, China and Pakistan initiated a project of the economic corridor (CPEC), with the signing of MOU in 2013. Figure 2 shows how CPEC connects Pakistan to China.

CPEC is planned to be completed by 2030 via infrastructural development, including a set of infrastructural construction to connect the western part of China, specifically, Kashgar, to the southern part of Pakistan, specifically, Gwadar. This connection is supposed to be developed via railways, highways, and oil and gas pipelines. The length of the road connecting Gwadar to Kashgar is $2700 \mathrm{~km}$.

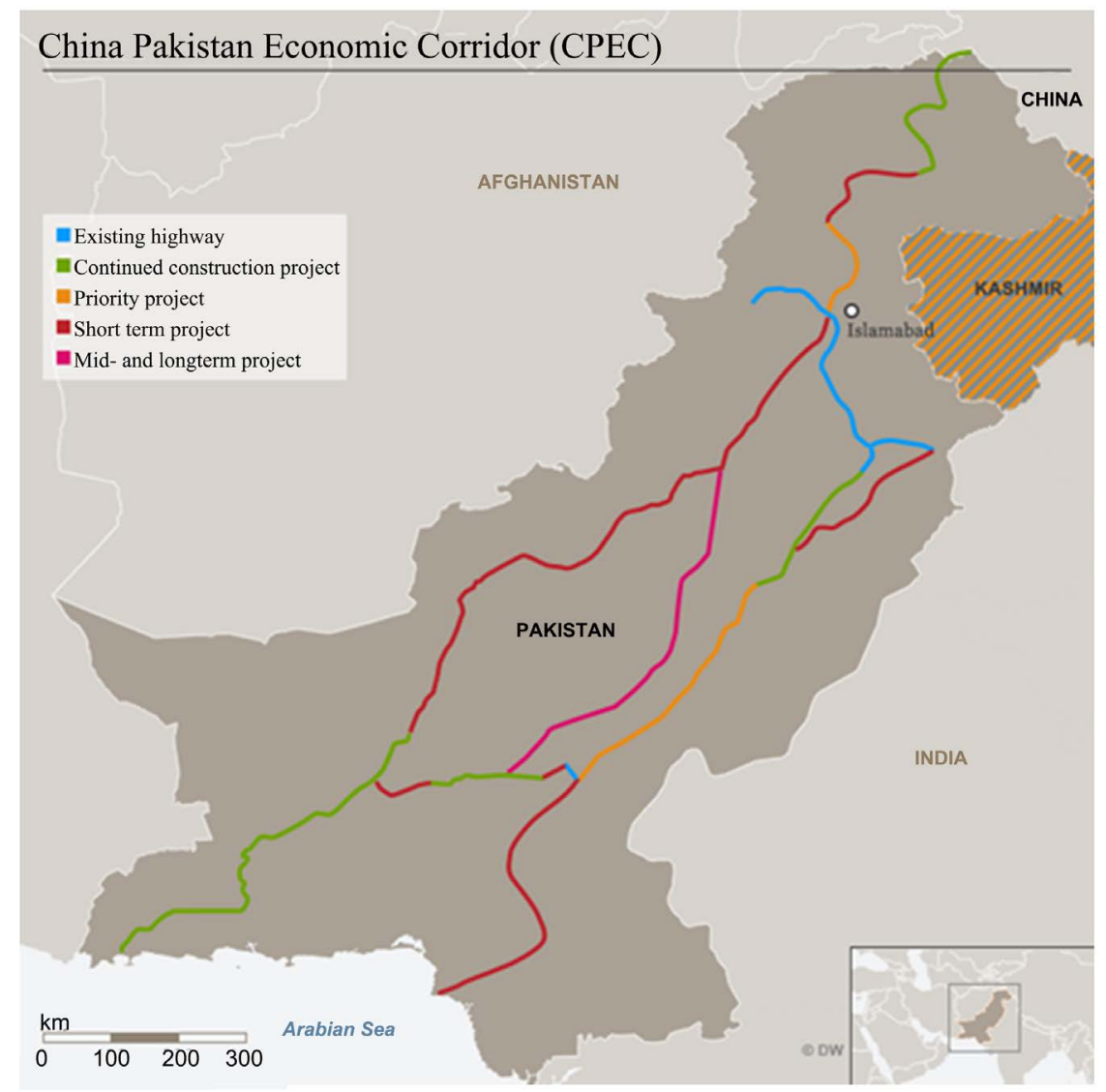

Figure 2. China-Pakistan economic corridor. 
After the CPEC project is completed, it forges a perfect logistic system and supports an open economic system for both China and Pakistan. While both Pakistan and China can benefit from the project, it is more significantly valuable in helping the economic growth and development of Pakistan. In addition to the logistic system, the development of energy and telecommunication infrastructure is also the leading project of the CPEC. Hence, this mega project is envisioned as a roadmap of substantial economic and technological development. CPEC has attracted global attention when the Chinese government announced that there was more than $\$ 46$ billion for this game-changer project in 2015.

The main objective of the CPEC project is to develop the Gwadar port as a trans-shipment port and a full-grown regional economic hub. The Pakistan government has established a free economic zone and announced Gwadar port as a duty-free port. These projects would accelerate the pace of economic growth and development in CPEC. The trade links of Gwadar port to North-Western India, Persian Gulf, East Africa, Central Asia is strategically significant. In Figure 3, the Gwadar port exhibits its importance in the development of CPEC.

As far as China is concerned, CEPC is more important and valuable. When CEPC comes to play, China can fulfill 60 percent of its energy requirements from the Persian Gulf through this route of Gwadar port. Compared to the route via Malacca strait, the Gwadar port can save the logistic cost significantly.

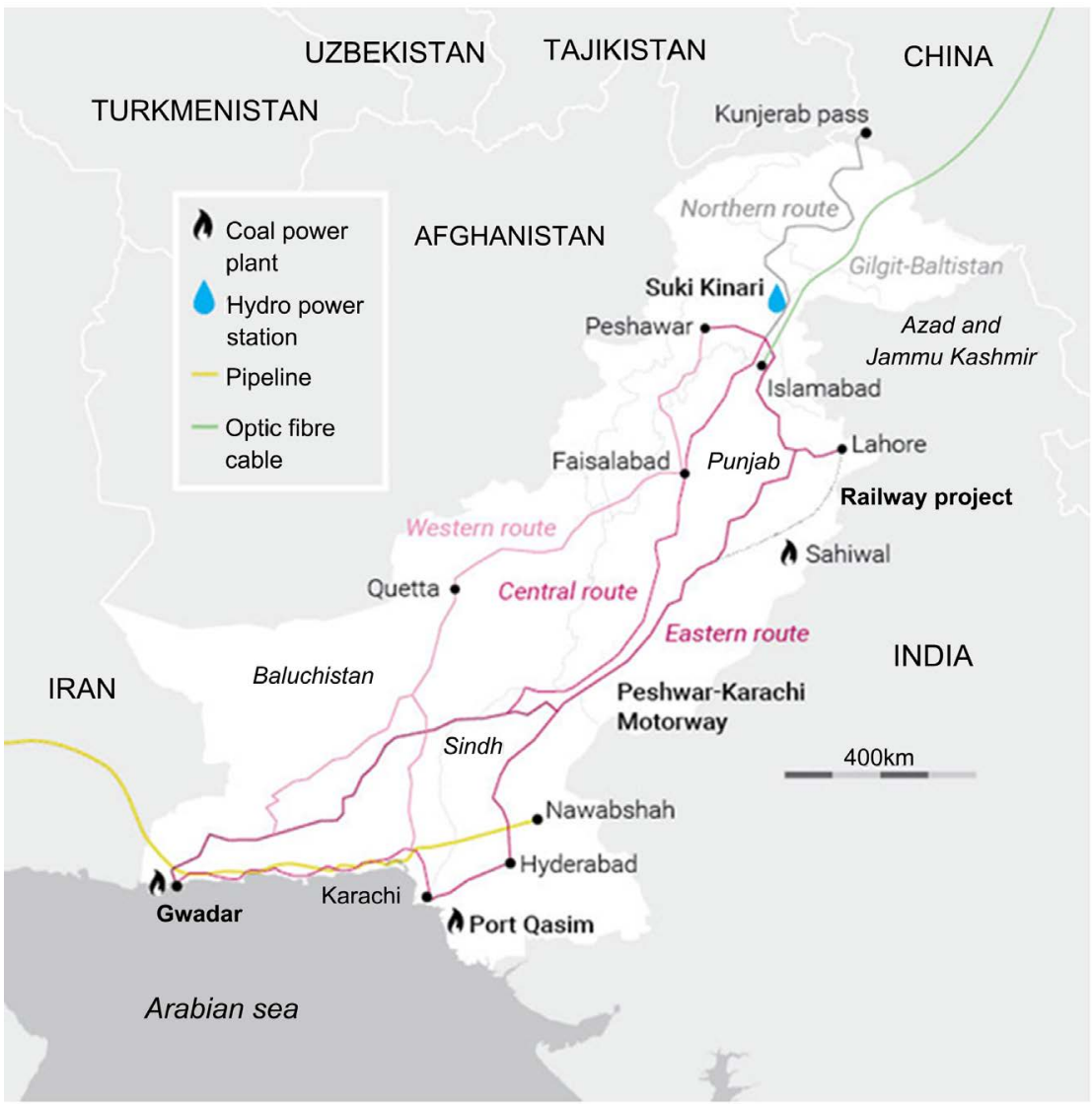

Figure 3. The Gwadar port. 
CEPC is constituted of seven major projects:

- Construction of railway tracks and highways,

- Infrastructure development of Gwadar port,

- Overcoming the issues of Energy generation and projection of power plant,

- Establishment of economic zones,

- Laying down of pipelines for gas and oil transmission,

- Development of Telecommunication and Cyber networking,

- Development of water supply system, especially for municipal use and industrial sector.

These seven projects constitute seven pillars to help Pakistan fulfill the longterm plan of development on tourism, energy, poverty alleviation, agricultural development, industrialization, and road connectivity.

The energy sectors, especially the power grid, electricity, oil, and gas, are the key considerations in the projects of CPEC as Pakistan is severely short of energy. CPEC highly focuses on the development of power plants by using new energies, such as wind, thermal, solar, hydro, and hybrid. Along with power generation, CPEC also invests heavily in pipeline and storages construction to acquire gas and oil resources.

In the area of industrial development, China will support Pakistan to improve the efficiency of its textile and clothing sectors and produce high value-added products. China will also facilitate Pakistan's industrial capacity in other industries such as engineering, construction material, chemical, iron, and steel. Kashgar is one terminal of CPEC on the side of China. China encourages regional trade by developing the Kashgar Economic and Technological Development Zone. Apparently, the development of Kashgar surely benefits Pakistan.

In the development of the agriculture sector and poverty reduction, the focus is on the advancement of agriculture infrastructure, agriculturists training, and technological exchange. Specifically, the agriculture part of CPEC focuses on biological propagation, production, processing, warehousing, transportation, and disease controlling. It can be expected that CPEC facilitates Pakistan's transition from traditional agriculture to modern agriculture and finally achieves poverty reduction.

As far as the tourism industry is concerned, Pakistan has rich resources for sightseeing, which will be fully utilized when CPEC is in progress. There are at least two areas, Pakistan-China border and coastal region in Pakistan, which are attractive for tourists and possesses the potential of tourism development. It can be expected that tourism would grow firstly in the Pakistan-China border area, where geographical advantages are significant. The tourism in Giligat-Baltistan region, which is adjacent to China, grows rapidly, with around one million people visiting this region in 2015-2016, a number not observed before.

CPEC pays great attention to urbanization since more and more human resources migrate to central cities as economies grow rapidly. There are projects in CPEC that aim to improve the comprehensive public service capabilities of different cities. For such purpose, the urbanization experiences of China and other 
counties will be drawn to help upgrade public transportation, water supply, and drainage system.

To advance CPEC, financial cooperation between China and Pakistan is necessary. For this reason, Pakistan and China have been established financial cooperation and policy coordination mechanisms at different layers. It highlights the financial reforms, financial innovation in products and services as well as the reduction of the financial risk, so as to develop a favorable financial environment. Both countries are also increasing cooperation between central banks and financial regulatory agencies concerning the settlement of RMB in cross-border trade.

\section{Hypothesis about Why CPEC Works: Balanced Growth and Big Push}

\subsection{Both China and Pakistan Can Benefit from CEPC}

As Pakistan is a typical developing country of bigger size, CPEC plays the role of an initial big push in its development.

Although neo-classical doctrine believing in a free market can explain well the economic growth of many developing countries, it is not a convincible theory to guide backward economies to start initial development. On the contrary, the structuralist theory of development, to which big push theory and balanced growth belong, is more helpful. If a country has established a thorough structure of the industry, it is a developing country and can rely on the market mechanisms. What it needs is gradual adjustments guided by market signals. Unlike developing countries, less developed ones need substantial changes so that they can sustain developments.

Pakistan was more of a less-developed country than a developing country. It lacked almost all perquisites for an economy to grow. There was no infrastructure, such as roads, power, warehouse, transportation system and ports, and deficient skilled worker. Therefore, while it did not have sufficient internal capital, overseas capital remained hesitating to move into this area. As a result, big bottlenecks impeded economic development in Pakistan. In order to bring the country into a sustained path of development, it has to improve the infrastructure system and invest in a set of comprehensive projects that are complementary in a balanced way. However, the balanced development strategies, of which big push strategy is a typical one, need enormous investment on a large scale at the same time, which unfortunately was scarce in Pakistan.

To acquire needed capital, economic openness to the world is the only solution. However, because the initial conditions were unsatisfactory, the profitability of investment was unfavorable for developed western countries. Besides, the political structure in Pakistan was not as stable as that in other developing countries, and there were also various conflicts created by religion faith and nationalities. The risk in security and politics caused uncertainty for the future of investment. As a result, Pakistan was not attractive for developed countries and 
hence failed to witness the substantial inflow of capital from developed countries.

Compared to developed countries, China has greater advantages in both costs and benefits. On the part of costs, China can employ skilled workers and excellent engineers with relatively lower compensation compared to any other countries. In addition, China is capable to produce various excellent facilities and equipment at a much lower cost. Therefore, it is cheaper to use capital from China and import facilitates and equipment from China.

On the part of benefits, China may benefit greatly from the CPEC plan. Firstly, after long term sustained growth, China has accumulated thorough and comprehensive productive capabilities. However, the productive capabilities of China have been excess in the last decade. China needs to find a way to utilize these capabilities. Secondly, the openness of China to the world economy relies heavily on a logistic system via Malacca Strait. On the one hand, Malacca Strait is expensive since it takes a long time and a long way to ship merchandise and oil from Europe and Middle East countries to China. Gwadar port can shorten the road half and hence save the cost and time. In addition, CPEC helps the development of northwestern provinces of China. On the other hand, the Malacca Strait is too narrow to be strategically safe. It can be used as a barrier to cut off a line of shipment to China when those powerful outside countries think necessary. Thirdly, when CPEC is completed, the Northwestern provinces and Pakistan will become integrated into an economic zone.

\subsection{How CPEC Helps Pakistan to Sustained Development}

Due to the development gap between China and Pakistan, two countries are complementary, as China and developed western countries were three decades ago. The complementarity can be used to benefit both China and Pakistan.

Once China invests in CPEC, it ignites the engine of economic growth in $\mathrm{Pa}-$ kistan. CPEC implies a balanced growth strategy via an initial big push. When economic growth in Pakistan begins, CPEC can sustain its own growth via catchup mechanism and converging mechanism. Catch-up effect means that less developed economies may leap over some stages along which developed economies must step during their economic development. China has kept high growth rates for more than four decades. Looking back at all the way that China has experienced, we can summarize many successful practices as well as failures. Pakistan may learn from China's experience, drawing successful experiences and avoiding failures. In addition, China can directly introduce adequate technologies and proper management skills in conducting projects and running the business in CPEC. With the help of CPEC, Pakistan becomes capable of avoiding the crooked road to development via CPEC.

As far as the converging mechanism is concerned, it is an optimistic feature that developing countries demonstrate in their earlier stage of economic growth. According to growth theory, if two countries have the same saving rate and 
technological growth rate, no matter how big the development gap is in the beginning, they will finally grow at the same rate and enjoy the same income per capita. In other words, the less developed country grows at a much higher rate than the developed one until the former catch up the latter in income per capita. Therefore, once CPEC begins and the government gets everything right, Pakis$\tan$ will grow fast automatically by itself.

The automatic growth can be ascribed to the different paths of capital accumulation and depreciation. Generally, while capital depreciates in roughly the same rate yearly, output and saving increases in a falling rate due to the law of diminishing returns. The high-income level countries are on such a stage that marginal return to capital is much lower. As a result, the new saving from new output can just meet the need that economies make up the loss of capital due to depreciation. It suggests that capital stock per worker no longer increases and hence output per capita ceases to increase. This situation is well known as a steady state. In such a steady state, economies can only realize the growth of income per capita via technological progress. However, compared to developed economies, developing economies are in the earlier stage of growth and far away from the steady state of the high-level output. In this stage, capital stock is so limited that the depreciation is small. Therefore, the loss of capital stock due to depreciation is smaller than the new formation of capital via saving and investment. As a result, capital stock per capita can increase year by year in the earlier stage of economic growth. The increase in capital stock per capita enables developing economies to grow faster than the developed ones but at a falling rate.

\subsection{Expected Benefits to Pakistan in the Future}

$\mathrm{CPEC}$ is a long-term plan continuing to 2030 with a total investment amounting to 54 billion US dollars. The strategic location of Pakistan provides a considerable significance to the CPEC project because, after completion, it will remarkably improve the economic, commercial and geostrategic position of the region. It will also help the deprived and underdeveloped provinces of Pakistan via reducing poverty, lowering unemployment and reducing inequalities. CPEC is regarded as a game-changer and win-win project in the region because it will generate massive trade and economic activities that will bring progress and prosperity to both countries.

CPEC solves the main blockages of Pakistan's economy by its diverse portfolios such as infrastructure connectivity, energy, industrial cooperation, and other factors. Doing so, CPEC projects are facilitating the country's infrastructure investment and improving the overall infrastructure performance, helping the ranking jump 23 points to reach 82nd in 2018 from 105th in 2012 (IMF, 2018).

CPEC has created a considerable number of opportunities for Pakistan to achieve socio-economic prosperity. On the one hand, to make use of these opportunities, Pakistan should focus on advanced industries such as artificial intelligence, robotics, renewable energy, agriculture, and biotechnology. To have 
these industries developed, it would be helpful for Pakistan to spotlight the central issue of training workers so that adequate technical human resources match the increasing investment. On the other hand, Pakistan should pay more attention to those long and highly deprived and underdeveloped areas, especially Baluchistan, which is also the resource-rich province. Baluchistan province has natural resources like oil and gas minerals, coal, construction material and various energies including renewable energy. Furthermore, Baluchistan has the potential to offer joint industrial projects with Chinese counterparts in areas like stones production, mining, and fish farming, which are limited in China mainland.

\section{Various Factors Influencing the Success of BRI and CPEC}

\subsection{Challenges from Socio-Political Structure of Pakistan}

Regardless of the strategic importance of CPEC to China and Pakistan, CPEC has also faced various challenges and threats for its proper completion, especially in regional security and political stability.

There is one obstructive factor to the development of CPEC, which is from a neighbor country in the region, India. Furthermore, the United Arab Emirates seems unhappy with Gwadar Port, since it competes with established Dubai. In response to Gwadar port, India and Iran have also initiated the Chahbahar port project. Nonetheless, Iran is noticeably comfortable and declares that both ports will complement each other while India has invested heavily in Chahbahar port. However, the Chahbahar project remains uncertain about building one or two berths, so Iran invited Pakistan and China to participate in the project. The purpose of the Chahbahar port is to provide smooth access to the surrounded area of Afghanistan and Central Asia region for energy imports from the Gulf countries and passageway to the broader region.

Whether CPEC is successful also depends on Pakistan's political stability. The political distress in the country is the primary hazard of carrying out of CPEC. Historically, Pakistan faced political instability due to different factors such as military intervention from outside powers and the tug of war between various political parties. The latest case occurred in 2014 regarding the election campaign, in which backlash against the CPEC project was reported. Various small political nationalist parties always criticized and blamed that CPEC had the potentials to weaken the sovereignty of Pakistan. The purpose of such allegations and negative opinions from various political parties is to leave the CPEC project unsuccessful. Even so, regarding the friendly relationship between Pakistan and China, a consensus could be reached among all the political parties, so CPEC may go well finally.

If Pakistan and China can cooperate to handle political stability, then the main challenge leftover is a security risk. The entire discouraging task for the successful development of CPEC projects is related to the security threat at both internal and external sides. While both Pakistan and China have their own in- 
ternal securities challenges in the recent past, Pakistan is severer, vulnerable to damages of terrorism and extremism. Extremists organizations are active from Xinjiang Uygur Autonomous Region of China to Gwadar region of Pakistan, including East Turkestan Islamic Movement (ETIM), Tehreek-e-Taliban (TTP), Lashkar-e-Tayyiba, Lashkar-e-Jhangvi, (LeJ), Daesh (ISIS), Balochistan Liberation Front (BLF), and militant wings of some political parties. They try to discontinue these megaproject activities in the region.

Similarly, there are some international forces active in the region against CPEC. These forces have been continually funding militant groups and sub-nationalist in the area to encourage them to conduct terrorist activities. It obviously threatens the success of CPEC projects. These groups also commit a crime of kidnapping only for ransom. They carried out an attack on a Chinese company doing equipment installation related to CPEC projects, having murdered many Chinese employees. The foremost security threats come from Afghanistan's Kunar and Nuristan province, where the majority of terrorist groups are located, such as Al Qaeda, Islam state (Self-styled), Tehreek-Taliban, the movement of Islamic Uzbekistan and Turkmenistan Islamic party. To guarantee the life security of CPEC workers, the Pakistan army has established a special force guarding CPEC projects. This recently initiated force includes special security division which consists of nine army battalions and six wings of political forces, namely the Rangers and the Frontier Force (RFC). Thus, we have to admit that the development of CPEC projects is costly.

If we turn our focus to the important province, i.e. Baluchistan province, we can see substantial obstacles to growth. Baluchistan is the largest province of $\mathrm{Pa}$ kistan in terms of area but the smallest in terms of population. Similarly, the socio-economic standing of Baluchistan province is least developed compared to other provinces. The big problem is its social structure, as its society is still tribally structured. People in this society are inadequately organized, less disciplined, neglected of authorities, and unskilled. Although Baluchistan province is rich in natural resources, due to small and unskilled population and negligence of authorities, any plans of development fail to utilize resources efficiently. Taking education as an example, the Baluchistan literacy rate stands at 51.5 percent, which needs serious attention. Moreover, because the labor force in this area is unqualified, its unemployment rate is as high as $20 \%$. And the provincial government fails to improve the capabilities, skill, and discipline of its labor force. The statistics suggest that Baluchistan province has a weak growth performance and lowest GDP per capita level over the past decade compared to other provinces.

In addition to obstacles in social structure and labor abilities, security risk caused by military conflicts is also noteworthy. The province is a conduit to link the Gwadar deep-water port in Pakistan with the city of Kashgar of China. The dissent Balochi believes that the CPEC project is unfair to the local deprived people of Baluchistan. The Balochi separatists attacked gas pipeline installation, 
in which many Chinese engineers were murdered. The complicated situation makes the province in anarchy and damages the development of CPEC projects. These separatists aim to keep Baloch people deprived of the significant advantages of CPEC projects.

\subsection{Unreal Worry of Chinese Imperialism}

When China initiates to promote projects of BRI and CPEC, it was naturally for other countries to worry about whether it is a new form of imperialism. As we know, while old-fashioned imperialism pursuits economic interest for capitalists via political impacts and military power, neo-imperialism seeks to make profits via monopolistic capital power. Both old-fashioned and neo-imperialism produce the same outcome of damaging the sovereignty of colonized countries, affecting their religious and cultural tradition while exploiting them of economic interest. However, the accusation of neo-imperialism does not apply in the case of China initiating BRI and CPEC. If China was enforcing imperialism over countries along the Belt and Road, it must have overwhelming monopolist power over countries along the Belt and Road and damage their sovereignty.

Obviously, it is not true. Imperialism refers to a vertical interaction of coreperiphery structure between the countries where the least benefits accrue to the periphery to maximize the profit of the core. However, we cannot find such a structure in terms of BRI either logically or historically. Globally, China is not the only source of capital funds available for countries along the Belt and Road. If profitable opportunities in the region are realized, every capitalist country would like to invest in the region and all countries have equal access to the region. Now only China is more optimistic about the future of economic development of the region and makes effective moves. Although China accounts for a major part of foreign investment, projects of BRI still have been disturbed all the time by the rotation of ruling parties and social instability caused by ethnic groups and various civilian forces. Even outside political forces have been exerting negative influences on the projects via lobbying political leaders and threatening to withdraw various aids. BRI projects were troubled in Malaysia, Sri Lan$\mathrm{ka}$, and the Maldives.

Because of the strategic partnership between China and Pakistan, there is no room for worry of neo-imperialism in the case of CPEC. Although the Chinese language is being taught in many universities and schools of Pakistan, Pakistani culture is seldom influenced. Every country is being reshaped by powerful culture in the world with developments of globalization, but their root of culture and history can be hardly shaken. Pakistan eagerly hopes to realize rapid growth but is short of capital. China has accumulated enormous productive capacity and is capable of equipping Pakistan with sufficient capital. Thus, CPEC is developed. So far, no change has been found in the context of ideology, philosophy, and religious perspective. CPEC benefits both China and Pakistan equally, so there is no room for imperialism. 


\section{Conclusion}

CPEC is an essential constituent of BRI. It is an indispensable project to start and promote BRI. The tremendous future economic growth is a dream of Pakistan and highly associated with the success of CPEC projects. The future growth of China is also highly affiliated with the successful implementation of BRI. The main agenda of China is to develop its western part by the utilization of its surplus capacity of construction companies, engineering industries, chemicals, and many other industries. Many countries along BRI will get benefits through learning management practices to bolster development in infrastructure, win-win trade, better investment policies, and socio-economic linkages. CPEC has attracted global attention when the Chinese government announced that there was more than $\$ 46$ billion for this game-changer project in 2015. With the help of CPEC, Both Pakistan and China can bring better life to their inhabitants and make their future safe. CPEC is for sure beneficial to the world economy as it can create a dynamic and vital economic zone. When CPEC helps BRI to go well, a new growth engine will emerge for the world economy.

Hence, this mega project is envisioned as a roadmap of substantial economic development, technological development and welfare improvement of the society. Although CPEC projects are beneficial to the economies along BRI, they are not free from challenges in terms of socio-political and economic threats. The KPK and Baluchistan provinces have many security threats and socio-political challenges. Because of these challenges, it seems to be difficult trying to complete CPEC before 2030. Nevertheless, the good news is, the Pakistan army is capable to control terrorist attacks. CPEC as a megaproject should be completed under the protection of the Pakistan army. As for ordinary laymen, such as workers and engineers, they should be aware of various dangers related to projects through local newspapers, local television and social media. Furthermore, the economic corridor is also troubled by law and order issues. Therefore, the provincial government needs to control these issues and challenges to make the business environment safe and orderly. Thanks to the peculiar strategic partnership between Pakistan and China, obstacles to CPEC projects can be easier to solve under this relation.

\section{Limitations}

The limitations of this research are demonstrated in this section. Information gathered is limited by the time when this research was completed, and thus imminent policy changes of Pakistan and China may influence the outcomes of analysis above. Therefore, further investigation is needed to keep track for the relevant changes in policy of BRI. Additionally, further quantitative research is needed for solid proof of the importance of CPEC.

\section{Conflicts of Interest}

The authors declare no conflicts of interest regarding the publication of this paper. 


\section{References}

Athukorala, P. C. (2014). Global Production Sharing and Trade Patterns in East Asia. In I. N. Kaur, \& N. Singh (Eds.), The Oxford Handbook of the Economics of the Pacific Rim (pp. 333-361), Oxford, UK: Oxford University Press. https://doi.org/10.1093/oxfordhb/9780199751990.013.014

IMF (International Monetary Fund) (2018). IMF Executive Board Concludes First PostProgram Monitoring Discussions with Pakistan.

Krugman, P. R. (1991). Geography and Trade. Cambridge, MA: MIT Press.

Mitra, S., Hasan, R., Sharma, M., Jeong, H. Y., Sharma, M., \& Guha, A. (2016). Scaling New Heights: Vizag-Chennai Industrial Corridor, India's First Coastal Corridor. Mandaluyong: Asian Development Bank.

Newman, C., \& Page, J. (2017). Industrial Clusters: The Case for Special Economic Zones. WIDER Working Paper. Helsinki: WIDER. https://doi.org/10.35188/UNU-WIDER/2017/239-7

PwC (PricewaterhouseCoopers) (2017). The World in 2050-Summary Report.

Rimmer, P. J. (2014). Asian-Pacific Rim Logistics: Global Context and Local Policies. Cheltenham: Edward Elgar Publishing. https://doi.org/10.4337/9781783478668

Schwab, K. (2018). Global Competitive Index 2018 Report. World Economic Forum.

Sender, H., \& Stacey, K. (2017). China Takes "Project of the Century" to Pakistan. Financial Times.

Sial, S. (2014). The China-Pakistan Economic Corridor: An Assessment of Potential Threats and Constraints. Conflict and Peace Studies, 6, 24.

Söderbaum, F., \& Taylor, I. (2001). Transmission Belt for Transnational Capital or Facilitator for Development? Problematising the Role of the State in the Maputo Development Corridor. The Journal of Modern African Studies, 39, 675-695. https://doi.org/10.1017/S0022278X01003767

World Bank (2009). World Development Report 2009. Washington, DC: World Bank.

Yeats, A. (2001). Just How Big Is Global Production Sharing? In S. W. Arndt, \& H. Kierzkowski (Eds.), Fragmentation: New Production Patterns in the World Economy (pp: 108-143), New York: Oxford University Press. 